\title{
THE STATUS OF THE COMMON SEAL (PHOCA VITULINA L.) ON THE EAST ANGLIAN COAST
}

\author{
By D. E. Sergeant \\ Department of Zoology, University of Cambridge
}

(Text-fig. I)

From time to time over a number of years the Fisheries Laboratory at Lowestoft has been asked to investigate aspects of the problem of the alleged harm to fisheries caused by the common seal. There are numerous colonies of these animals off the East Anglian coast, frequenting especially the sandbanks of the Wash, which dry out at low water, and therefore form secluded resting places.

It would be a major undertaking to make a full estimate of damage done by the seals, whether this is large or small; but evidence on which a judgement can be based has been collected, and is given in the following pages. This evidence is often inconclusive, but in one locality it clearly shows harm done by the seals, and in the author's opinion it would be prudent from time to time to reduce the number of seals, incidentally finding a commercial use for the meat and hides.

The evidence comes from an investigation of the food of the seals, and of their numbers, to which are added some notes on their biology.

This work was carried out in the summer of I947 and the spring of 1948 at the Fisheries Laboratory, Lowestoft, and grateful acknowledgement is made of help given by members of the staff of the laboratory in its progress. I am particularly indebted to the director, Mr Michael Graham, for allowing me to incorporate the results of his own earlier investigations in this paper, for reading through the manuscript and suggesting improvements, and for encouraging its publication.

I am grateful also to Dr G. C. L. Bertram, Dr F. Fraser Darling and Mr P. H. T. Hartley, for valuable criticism and advice, and to Dr Bertram for the loan of several papers otherwise unobtainable.

Finally, I am indebted to Prof. James Gray for permission to submit the paper for publication while I have been engaged on other research work under his supervision.

\section{FooD}

Altogether 194 stomachs of seals obtained in the Wash district during 1947 were examined, 2 of these with the complete gut. In addition, 6 stomachs from the Blakeney district of the Norfolk coast, and 2 unpreserved stomachs from 
seals killed on the Scroby Sand, off Yarmouth, were examined. The last were sent by Messrs Pettit of Reedham. All the rest were sent by the Eastern Sea Fisheries Joint Committee, while a scheme was in operation under which fishermen received a bounty for each stomach collected and preserved in formalin. These were forwarded to the Fisheries Laboratory in milk-cans for examination.

To supplement the results of these examinations a 3-day visit was made by the author in April I948 to King's Lynn and the coast of North Norfolk as far east as Sheringham, and inquiries were made of fishermen at Lynn, Wells, Brancaster, Blakeney and Sheringham. These inquiries yielded eye-witness accounts of the feeding of seals and the stomach-contents in freshly killed seals. The author has, in addition, observed seal herds in the Wash on several occasions, and has been able to study the bottom fauna brought up by the trawls of shrimping vessels in that estuary, as an indication of the food available to the seals there.

Of the 202 stomachs examined, all came from seals killed between June and September, with the exception of the two from Scroby Sand which had been killed in March. Thus the results do not indicate a complete year's feeding habits, and more spring-killed seals would have been desirable, for example, to examine for remains of sea-trout (which appear to be caught off the Norfolk coast by the fishermen in May).

Only date and position of capture were given with the stomachs, with no information available as to the size or sex of the seals from which they had been taken. However, it was possible to distinguish the young and first-winter animals by the small size and thinness of their stomachs. All other stomachs are labelled 'adult'. Of this total of 202 stomachs, 106 were those of young seal pups, containing (if anything) only milk. Of the remaining 96 , only 25 contained recognizable food remains; so that the number does not permit of a quantitative evaluation of the food eaten. However, it has been possible to confirm the results from earlier work, previously unpublished, carried out by Mr M. Graham from 1926 to 1930 on the food of seals in this region. These results are included in the tables (see Table I separately and together with the results of the present investigations.

To account for the small percentage of stomachs containing any food remains at all it is presumed that most of the seals were killed while resting on sandbanks at low water, some time after their last meal. Digestion in these animals is very rapid, all traces of food having left the stomach within $3 \mathrm{hr}$., according to Havinga (1933).

From the data available, the food of seals frequenting the Wash may be summarized as follows:

The pups are suckled for at least a month. Havinga (1933) gives 6 weeks from birth to weaning, and my results indicate about the same time-all pups were feeding on milk up to Io July, and some were still unweaned by the 25 th. 
However, some began to feed on shrimps about I2 July onwards, and these became the predominant food until about the middle of October. Havinga also found, from analyses of stomach contents, that young seals on the Dutch coast fed largely on shrimps in their first autumn.

\section{Table I. Summary of Food found in Stomachs of Seals from the WASH (ADUlT AND IMMATURE), I929 AND I947}

\begin{tabular}{|c|c|c|c|c|c|c|}
\hline \multirow[b]{2}{*}{ Species } & \multicolumn{3}{|c|}{$\begin{array}{l}\text { No. of stomachs } \\
\text { in which found }\end{array}$} & \multicolumn{3}{|c|}{$\begin{array}{l}\text { Total number of } \\
\text { individuals of species }\end{array}$} \\
\hline & $\begin{array}{l}\text { Graham } \\
\text { I929 }\end{array}$ & $\begin{array}{l}\text { D.E.S. } \\
\text { I } 947\end{array}$ & Total & $\begin{array}{c}\text { Graham } \\
\text { I929 }\end{array}$ & $\begin{array}{l}\text { D.E.S. } \\
\text { I } 947\end{array}$ & Total \\
\hline $\begin{array}{l}\text { Fisn: } \\
\text { Flatfish } \\
\text { (Pleuronectes spp.) }\end{array}$ & 5 & 2 & 7 & c. I5 & 2 & c. I7 \\
\hline Whiting (Gadus merlangus) & 2 & I & 3 & 2 & I & 3 \\
\hline Sand eel (Ammodytes sp.) & I & - & I & I & 一 & I \\
\hline Salmonid (?) & 一 & I & I & - & I & I \\
\hline Pipefish (Syngnathus sp.) & - & I & I & - & I5 & I5 \\
\hline Unidentified & $\mathrm{I}$ & I & 2 & I & I & 2 \\
\hline Mollusca: & & & & & & \\
\hline $\begin{array}{l}\text { Common whelk (Buccinum } \\
\text { undatum) }\end{array}$ & I7 & 6 & 23 & I58 & I4 & I 72 \\
\hline Squid (Loligo sp.) & 一 & 3 & 3 & - & 5 & 5 \\
\hline Mussel (Mytilus edulis) & 一 & 3 & 3 & - & 8 & 8 \\
\hline Cockle (Cardium edule) & 4 & 2 & 6 & 4 & 2 & 6 \\
\hline Crustacea: & & & & & & \\
\hline $\begin{array}{l}\text { Common shrimp (Crangon } \\
\text { vulgaris) }\end{array}$ & 5 & 9 & I4 & I IO & 245 & 355 \\
\hline Prawn (Pandalus montagui) & I & - & I & 50 & - & 50 \\
\hline $\begin{array}{l}\text { Crabs (Carcinus or Portunus } \\
\text { sp.) }\end{array}$ & - & I & I & - & I & I \\
\hline $\begin{array}{l}\text { Hermit crabs (Eupagurus } \\
\text { spp.) }\end{array}$ & I & I & 2 & I & I & 2 \\
\hline Unidentified & I & - & I & 2 & - & 2 \\
\hline
\end{tabular}

Totals calculated by weight at time of assimilation, including shell weight for the Mollusca: all fish $4 \%$, Mollusca $92 \%$, Crustacea $4 \%$.

There is thus after weaning a transitional shrimp-eating stage. Then, in their first winter, the seals become more omnivorous and eat fish, crabs, etc., as well as shrimps. As may be seen from Table I, the food of adult seals in the Wash appears to be predominantly the Common Whelk (Buccinum undatum L.), the opercula of which were found alone and in some numbers in many stomachs, in both investigations. Fish are not a large item, but flatfish (Pleuronectes spp.), whiting (Gadus merlangus L.), pipefish (Syngnathus sp.), and salmonid remains were identified from whole remains, otoliths, or vertebrae. Other food includes squids (Loligo, sp.), shrimps, hermit crabs (Eupagurus sp.), true crabs (Carcinus maenas Penn. and Portunus sp.), and small mussels (Mytilus).

The sample from Blakeney shows a complete contrast. The number of stomachs was relatively small, but most were full, and showed an overwhelming preponderance of fish-remains. Reports from fishermen confirm these piscivorous tendencies. Apart from flatfish (Pleuronectids) and gobies (Gobius 
minutus Gmelin) which were found in the stomachs sent in, soles, eels, mackerel and sea-trout are said to have been found in stomachs opened by the fishermen themselves in the past, and in addition seals have been watched feeding on skates and cod.

No food remains were found in the two intestines examined.

It is possible that the percentage of fish has been underestimated, since (i) the small fish otoliths would pass out of the stomachs more rapidly than the larger whelk opercula, etc., and (ii) the heads of fish may, according to eyewitnesses, be bitten off, and rejected, leaving only the more rapidly digested vertebral column for recognition.

\section{TABLE II}

A. Food Found in Stomachs of Seals from Blakeney (six Stomachs, THREE CONTAINING FoOd ReMAINS, OCTOBER-December, I947)

\begin{tabular}{lccc}
\multicolumn{1}{c}{$\begin{array}{c}\text { Species } \\
\text { Dab (Pleuronectes limanda) }\end{array}$} & $\begin{array}{c}\text { No. of } \\
\text { stomachs }\end{array}$ & $\begin{array}{c}\text { No. of } \\
\text { individuals }\end{array}$ & Remarks \\
$\begin{array}{l}\text { Plaice }(P . \text { platessa) } \\
\text { Flounder }(P \text {. flesus) }\end{array}$ & 3 & c. 90 & $\begin{array}{c}\text { All IO-I2 cm. } \\
\text { in length }\end{array}$ \\
Common goby (Gobius minutus) & 2 & c. I2 & - \\
Unidentified elasmobranch & I & I & - \\
Shrimp (Crangon) & 2 & 2 & - \\
Hermit crab (Eupagurus bernhardus) & 2 & 2 & - \\
Crab (Portunus sp.) & I & 8 & - \\
Mussel (Mytilus) & I & I & -
\end{tabular}

\section{B. Food Found in Stomachs of SEALS From Scroby Sand (TWO STOMACHS, April I948) \\ $\begin{array}{ll}\text { (i) I pleuronectid } & \text { (ii) } 3 \text { shrimps (Crangon) }\end{array}$}

Some of the smaller invertebrates may have been taken as secondary food, i.e. that eaten by the seal's prey; but this has been considered for each individual, e.g. small worms (Lagis sp.) associated with flatfish were certainly the food of the latter, but crabs with a carapace width of $c .25 \mathrm{~mm}$. in the same stomach could not have been so. The whelks must certainly have been taken directly, as they were never associated with any fish remains.

Thus the results for adult seals from the Wash contrast strongly with those from the open coast at Blakeney. Examinations of shrimpers' catches in the Wash show that shrimps form the great bulk of the free bottom fauna, while fish of any size are rare. Small flatfish of $2-3$ in. in average size, small gadoids and the common goby are the principal small fish brought up in these finemeshed trawls, together with occasional sprats (Clupea sprattus L.), the seasnail (Liparis montagui Don.), and the armed bullhead (Agonus cataphractus L.). Whelks are presumably common: although the trawls do not take them, there are local fisheries for whelks at Brancaster and Wells just outside the bay of the Wash. In the Wash there are no inshore fisheries dependent on fish, as there 
are on the open coast. All the boats at Lynn and Boston are used either for shrimp-trawling, or for gathering cockles (Cardium edule L.) or mussels from the beds in the Wash. The evidence suggests, therefore, that the common seal in this district has catholic tastes in its choice of food, fish comprising the normal or 'first-class' food, and invertebrates predominating when fish are difficult to secure. All of the animals upon which the seals feed, with the exceptions of the squids, are bottom-living. The substratum in shallow water along the coast and in the outer part of the channels of the Wash is clean sand, grading into mud, and finally into heavy estuarine clays in the river-channels of the Great Ouse, Nene, Welland and Witham.

Havinga found the seals of the Dutch coast to be feeding almost exclusively on fish, which together accounted for about $97 \%$ by weight of the total food. The most important species, in descending order, were: flounder (Pleuronectes flesus L.) $30 \%$, whiting (Gadus merlangus L.) I7 \%, herring (Clupea harengus L.) I5 \%, and the bullheads (Cottus scorpius L. and Agonus cataphractus L.) together I6\%. Shrimps, eaten mainly by the young seals, made up the bulk of the remaining $3 \%$ of invertebrate food, which also included a few cuttlefish (Sepia officinalis L.). Whelks were not recorded at all, and Havinga was sceptical of the earlier findings, then unpublished, which have been included in this paper. But as he used exactly the same methods of computation after analysis of stomach contents, one can only conclude that whelks are a food taken but locally. The seals on the Dutch coast, which included herds both on the open coast and in the channels of the Scheldt-Maas estuary, were thus found to have a diet resembling in a general way that of seals on the Norfolk coast, directly across the North Sea, as far as one can say from the relatively few data available from the English side. No doubt a more extensive investigation would show a more detailed correlation with the relative abundance or scarcity of individual food species in different areas and at different seasons. However, it seems strange, when one considers how much richer are the inshore waters of the Dutch coast than those of the opposite North Sea coast in young plaice, to find that this species comprised only some $3 \%$ of the total fish-food in Havinga's investigations.

Scheffer \& Sperry (I93I) (and see also Scheffer \& Slipp, I944), studied the food of the subspecies Phoca vitulina richardii (Gray) on the Pacific north-west coast of the United States. Their results, based on analysis of eighty-one stomachs with food-remains, were as follows: fish $93.6 \%$ by volume, mollusca $5.8 \%$, and Crustacea $0.6 \%$. The most important fish were: Pleuronectidae, various gadoids, the Pacific herring (Clupea pallasii), and various Cottidae, in that order; the Mollusca: squids, an octopus, and a bivalve (Yoldia myalis); the Crustacea: shrimps (Crago spp.), crabs, and the burrowing prawns Upogebia and Callianassa. These data show a striking similarity to those of Havinga (with respect to the principal families and genera, though not of course, the species, of the fish) and to the data here presented, with respect to the 
available invertebrates. Thus it seems that within a wide range of available food animals certain types seem to be preferred. The most easily available of these in any one locality and at any given season will then bulk largest in the diet, and the seals may (as in the Wash) adapt themselves permanently to feeding almost exclusively on one or two of these forms.

This adaptiveness in feeding-habits agrees well with what one knows of the highly developed adaptive behaviour of the common seal in other ways, for instance its rapid learning of relative safety or danger in different circumstances. It will also mean that food is not likely to be a limiting factor in the distribution of the species.

In fact, Phoca vitulina on the coasts of Europe ranges from the Mediterranean and Portugal to Iceland and the White Sea (Doutt, I942), and within the British Isles where it is widespread the range of habitats is a wide one, not apparently related to any particular type of coast. Thus, common seals are found in the sea lochs of the Western Highlands and the Hebrides, and along the exposed coasts of the Shetlands, as well as in estuaries and on sandy coasts as in the east of England and Scotland. The only general preference that can be noted is for sandy coasts, with sandbanks or low islets on which the herds can haul out at low tide.

By contrast, the grey seal (Halichoerus grypus F.) keeps to more remote islands and coasts, always on exposed shores. It appears to be a more specialized fish-feeder (as one might guess from comparing its sharply pointed teeth with the more lobose cusps of the common seal's), and it hunts especially the Gadidae and other inshore fish of rocky coasts (Darling, I948, p. 222). However, it is a species which is very vulnerable at the breeding season, since the young cannot swim until some days after birth, and do not naturally enter the water for some weeks. Persecution by man has undoubtedly confined it to the more remote islands.

Of other members of the genus Phoca, the harp seal (P.groenlandica Müll.) of the Arctic feeds on pelagic crustacea and fish (Sivertsen, I94I), as does the ringed seal ( $P$. foetida Müll), which was found by Dunbar (I94I) to feed in the Canadian Arctic chiefly on the amphipod Themisto libellula.

\section{Population}

An inquiry was carried out in the spring and summer of I948, with the help of local fishery officers of the Eastern Sea Fisheries Joint Committee, in order to find the approximate numbers of seals along the east coast from south Lincolnshire to Suffolk. Officers were asked to count the herds on sandbanks frequented by seals in their respective districts, where possible on several dates as a check. The response was good, the whole coast from Skegness to Yarmouth being covered, and the writer wishes to express his thanks to the fishery officers concerned for this information. The counts were made chiefly between 
April and June, i.e. at a time when the population, prior to breeding, should be at a maximum, while as yet no young would be present to complicate the estimate.

Details of the counts, with previous counts and estimates of the total number of seals in the Wash and of the number killed in each of these years, are given in Table III. Data for years other than 1948 were taken from unpublished records in the possession of the Fisheries Department. I948.

The accompanying map shows the approximate positions of herds located in

\section{Table III. Summary of Data on Seal Population in various} YEARS, FROM I9I2 TO 1948

\begin{tabular}{|c|c|c|c|c|c|c|}
\hline Sand & I9I2 & 1920 & I924 & 1928 & I947 & I948* \\
\hline Scroby Sand & - & - & - & - & - & $\begin{array}{l}\mathrm{I} 20-\mathrm{I} 40 \\
\text { c. } \mathrm{I} 50\end{array}$ \\
\hline $\begin{array}{l}\text { Blakeney Point } \\
\text { Burnham Overy }\end{array}$ & 二 & 二 & 二 & 二 & 二 & $\begin{array}{l}\text { c. } 150 \\
\text { IO-20 }\end{array}$ \\
\hline Total for open coast & - & - & - & - & - & $280-310$ \\
\hline Woolpack Middle Sand & - & 一 & c. 50 & - & $-\overline{-}$ & c. 150 \\
\hline $\begin{array}{l}\text { Blackguard Sand } \\
\text { High Soft or Seal Sand }\end{array}$ & - & 一 & - & - & (I8 killed) & \\
\hline $\begin{array}{l}\text { High Soft or Seal Sand } \\
\text { Thief Sand }\end{array}$ & - & 二 & - & - & (I9 killed) & $40-50$ \\
\hline Inner Westmark Knock & 二. & 二 & 二 & 二 & (2I killed) & 150 \\
\hline Old South & - & - & - & - & (53 killed) & $\begin{array}{l}20-30 \\
80-120\end{array}$ \\
\hline Gat Sand & - & - & - & - & (4 killed) & - \\
\hline $\begin{array}{l}\text { Hook Hills } \\
\text { Black Buoy Sand }\end{array}$ & 二 & 二 & 二 & 二 & $\overline{(x-110}$ & IO-I4 \\
\hline $\begin{array}{l}\text { Black Buoy Sand } \\
\text { Roger Sand }\end{array}$ & $\overline{20}$ & $30-40$ & 200 & 二 & (3 killed) & $28-34$ \\
\hline Ants & - & 50 & - & - & - & 30 \\
\hline Long Sand & 300 & 50 & - & - & - & $\begin{array}{l}\text { 'Hundreds' } \\
40 \text { (Sept.) }\end{array}$ \\
\hline $\begin{array}{l}\text { Inner Dog's Head } \\
\text { Inner Knock }\end{array}$ & 350 & 400 & 300 & - & - & IOO (Sept.) \\
\hline $\begin{array}{l}\text { Inner Knock } \\
\text { Wainfleet Mains }\end{array}$ & 50 & 100 & 100 & 二 & 二 & $\begin{array}{l}30 \text { (Sept.) } \\
43 \text { (Sept.) }\end{array}$ \\
\hline Total for Wash & '2000' & $\begin{array}{l}750 \\
\text { counted }\end{array}$ & $\begin{array}{c}\text { 'Very } 7 \\
\text { abundant' }\end{array}$ & $750-1000$ & - & $750-850$ \\
\hline Total killed in Wash & c. 100 & - & I50 & $200 ?$ & 300 & 100 \\
\hline
\end{tabular}

The totals given by these counts for the year 1948 are: $750-850$ for the herds in, and on the margins of, the Wash, and 300 for the herds along the Norfolk coast, giving a total of between IO5O and II50 seals. In spite of the usual human tendency to estimate too high, this is probably an underestimate, since (i) the number counted on a sand at any time is unlikely to include all the seals in the vicinity (some being in the water may easily be missed); and (ii) a herd or two probably went unrecorded. Repeated counts over a period of some weeks at several sands showed that these herds did not fluctuate greatly in numbers, and therefore probably remained as fairly static units which did not move about to different sands to be recorded more than once. I would therefore estimate about 850 seals as the approximate population in the Wash. This is of 
the order of magnitude of earlier estimates, e.g. 750 counted in 1913, and 750-1000 estimated by Mr Graham during the 1928 investigations. The annual toll of seals in the Wash has varied from about roo to 300, with an average of (say) 200. Havinga (I933) concluded that in Holland an average toll of rooo per annum was maintained for many years from a computed stock of 4000 ; but his graph, in fact, shows a slight decline, and a later rise after 3 years of diminished killing during the First World War.

On this basis the Wash population (excluding the Norfolk coast herds), averaging between 800 and I000, would remain more or less constant with an average kill of about 200. The number killed in 1947 was well over 300. In I948 about Ioo seals from the Yarmouth, Boston and Stiffkey (Blakeney) districts were received by a Norfolk firm, and doubtless the total number killed was considerably greater.

We may therefore give the total normal population in the whole area of the census as between I000 and I500 animals. Clearly the census method used is by no means an ideal one for this species. Counting from slow-flying planes should be a method eminently suitable for herds spread out on these flat sand-banks; not only would there be less disturbance, but the whole area could be surveyed over a short period during one low tide, thus eliminating the risk of duplicating counts in individual herds.

\section{Biological Notes}

Havinga, with Scheffer \& Slipp, have summarized most of what is known of the life history and ecology of Phoca vitulina in two widely separated sections of its range; but a few points of interest may be noted from the present inquiry.

There are said to be fewer seals in the Wash during the winter. This may represent merely a splitting up of the herds into smaller groups-a decreased gregariousness - or it may represent a partial migration to the outer coast, occasioned by the migration to deeper water of the bottom fish and invertebrates (e.g. the decapod Crustacea) which is known to occur in winter. The former seems the more likely explanation, since should the latter be true the herds along the coast might be expected to increase in size, or at least to be unaffected, by contrast, which is not so. The herds increase in numbers in the spring, and reach a maximum in June, when the young are born. Scheffer \& Slipp mention similar fluctuations on the coast of Washington.

In I948 the first young were seen, at different sands, on I7 and I8 June; in I947 young seals were killed in numbers from 23 June. To the writer's knowledge, no one has observed the actual process of birth in this species; should it occur on the tidal sandbanks it must presumably occur at low water, although the pups can swim immediately after birth.

It will be noted from the map that the Norfolk coast herds are larger, while 


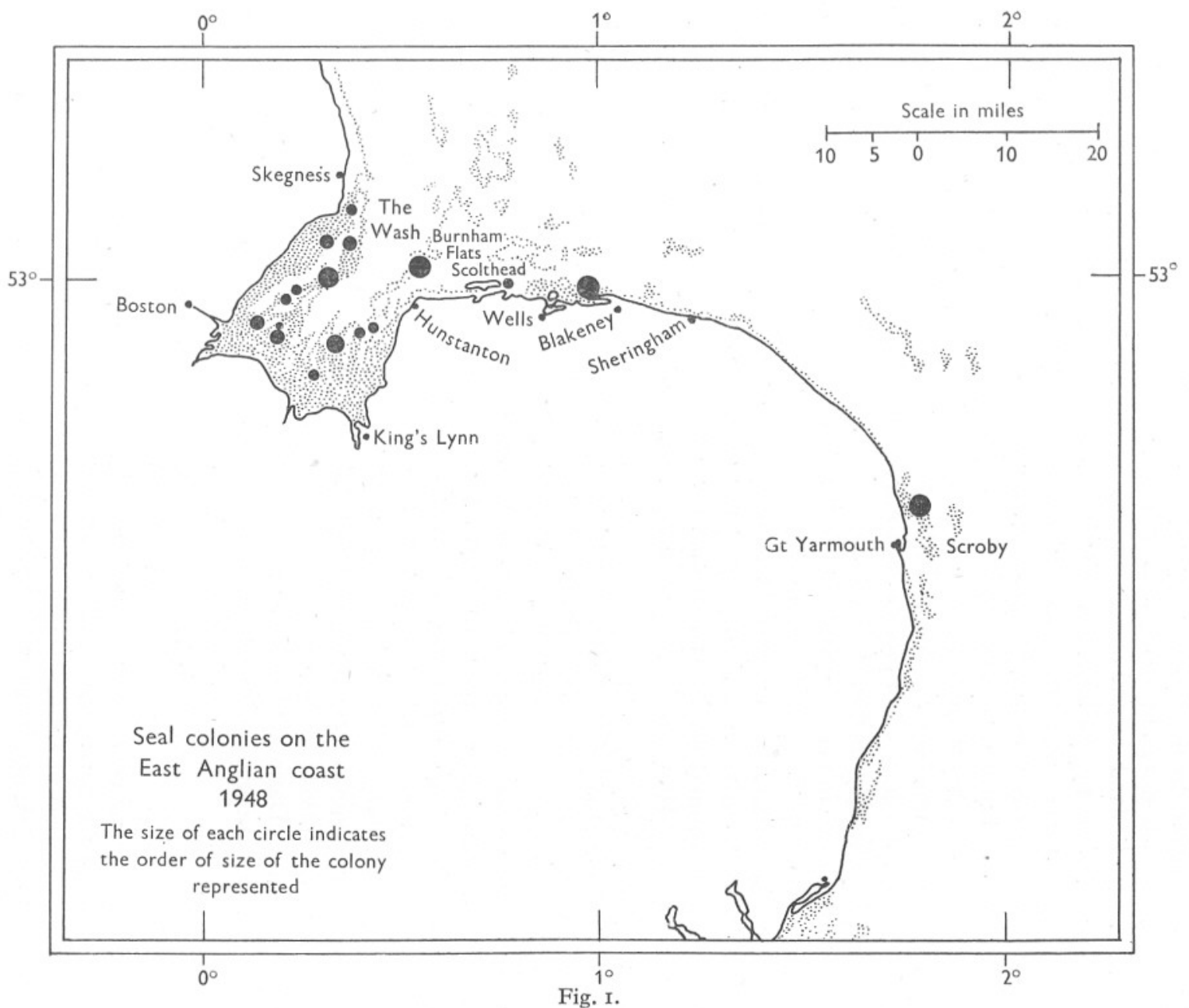


farther apart from each other, than those in the Wash. This is no doubt due to the scarcity of suitable sands along the outer coast, which leads to local concentration. These herds probably disperse farther to feed; seals are reported frequently all along the coast, as at Brancaster harbour and the west end of Scolt Head Island, in and outside the harbour at Wells, off Sheringham, and off Winterton and Palling 'especially when the herring drifters are about'. Reports of seals, including single females with pups, off Orfordness and in the Suffolk estuaries may represent incipient colonization in this region or merely an occasional drift down the coast from the Scroby herd off Yarmouth.

These coast herds seem to have increased considerably of recent years; thus according to one observer the colony on the Woolpack Sand numbered some 50 in 1925 , while it is now given as 150 , and in spite of persecution the Blakeney herd has steadily increased in numbers. It seems likely that these increases have been due in part to recruitment from elsewhere, but it is impossible to say how static and isolated the separate colonies really are until marking experiments have been carried out on these seals. It should be possible to mark the pups successfully. In the White Sea, pups of Phoca groenlandica were marked with aluminium disks pierced through the web of the tail in a similar manner to plaice-marking, and their movements traced from subsequent recoveries (Sivertsen, I94I).

In many parts of its range the common seal is known to ascend rivers to a considerable distance from the sea. Records of seals in the fenland rivers are not uncommon; one was shot in the Great Ouse at Hemingford Abbots (45 miles up the river and just below the first lock) on I6 January I947, and one frequented the Yare between Reedham and Surlingham from late September to early November, I947 before it was killed. These and other similar records have all been of immature seals in autumn and winter (August to January), which may indicate that seals of this age wander more than the adults. They cause considerable damage to the stocks of fresh-water fish in such small rivers, and rarely survive for long.

Dr Fraser Darling informs me that the young of grey seals are likewise more prone to wander than the adults.

\section{SUMMARY}

A study has been made of the food, population, and some aspects of the ecology of the common seal (Phoca vitulina L.) along the East Anglian coast.

Examination of stomach contents of I94 seals killed in the Wash in 1947 confirms earlier evidence that the species here feeds largely on whelks (Buccinum undatum). The food is estimated by weight as $92 \%$ molluscs, $4 \%$ fish and $4 \%$ Crustacea. Young seals for 2-3 months after weaning feed almost exclusively on shrimps (Crangon vulgaris).

Data derived from six stomachs, together with verbal reports, suggest that 
seals on the open coast feed more exclusively on fish, chiefly pleuronectids. This agrees with the findings of other workers in Holland and Washington State, U.S.A., that fish are the primary food animals. It is therefore suggested that in the Wash, where suitable breeding sands are common, the seals have become adapted to feeding on a 'second-class' food in the absence of dense stocks of fish.

Counts of all the seal herds located between Skegness in Lincolnshire and Yarmouth in Norfolk in the summer of 1948 gave as an estimate of the total population I000-I 500 individuals. This agrees broadly with the figure deduced from the number of seals killed annually. Comparison with estimates over the last 25 years shows that the species maintains its numbers in spite of intense persecution, several large herds on the Norfolk coast having in fact noticeably increased.

The herds appear to be sedentary, though a slight spring increase in size, probably due to a more marked gregariousness, has been noted. Immature seals frequently ascend rivers and may therefore be more prone to wander than adults.

The young are born from mid-June in this region.

It is concluded from the results of the food investigations that there is local damage to inshore fisheries, though the main part of the stock probably does not have any serious effect on fisheries for shrimps and shellfish.

\section{REFERENCES}

Darling, F. Fraser, 1948. Natural History in the Highlands and Islands. London.

Doutt, J. K., 1942. A review of the genus Phoca. Ann. Carneg. Mus. Pittsburgh, Vol. 29, pp. 6I-I25.

Dunbar, M. J., I94I. On the food of seals in the Canadian Eastern Arctic. Canad. Fourn. Res.; Section D, Vol. 19, pp. 150-5.

Havinga, B., I933. Der Seehund (Phoca vitulina L.) in den Holländischen Gewässern. Tijdschr. Ned. Dierk. Ver Leiden, Ser. 3, D. 3, pp. 79-III.

Scheffer, T. H. \& Slipp, J. W., I944. The Harbor Seal in Washington State. Amer. Midl. Nat., Vol. 32, pp. 373-416.

SCHEFFer, T. H. \& SPERRY, C. C., I93I. Food habits of the Pacific Harbor Seal (Phoca richardii). Fourn. Mammal. Baltimore, Vol. I2, pp. 2I4-26.

Sivertsen, E., I94I. On the biology of the Harp Seal (Phoca groenlandica Erxl.). Hvalråd. Skr., Nr. 26, I66 pp. 